\title{
TOWARDS SUSTAINABLE LAND MANAGEMENT IN THE DRYLANDS: SCIENTIFIC CONNECTIONS IN MONITORING AND ASSESSING DRYLAND DEGRADATION, CLIMATE CHANGE AND BIODIVERSITY
}

\author{
A. L. COWIE ${ }^{1 *}$, T. D. PENMAN ${ }^{2}$, L. GORISSEN ${ }^{3}$, M. D. WINSLOW ${ }^{4}$, J. LEHMANN ${ }^{5}$, T. D. TYRRELL ${ }^{6}$,

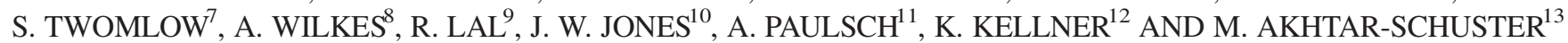 \\ ${ }^{1}$ National Centre for Rural Greenhouse Gas Research, University of New England, Armidale, NSW, Australia \\ ${ }^{2}$ Forest and Rangeland Ecosystems, Science and Innovation, Industry and Investment NSW, PO Box 100, Beecroft, NSW, Australia \\ ${ }^{3}$ Unit Transition Energy and Environment, Flemish Institute for Technological Research, Mol, Belgium \\ ${ }^{4}$ International Crops Research Institute for the Semi-Arid Tropics (ICRISAT), Hyderabad, Andhra Pradesh, India \\ ${ }^{5}$ Department of Crop and Soil Sciences, Cornell University, Ithaca, NY 14853, USA \\ ${ }^{6}$ United Nations Environment Programme World Conservation Monitoring Centre (UNEP-WCMC), Cambridge, UK \\ ${ }^{7}$ United Nations Environmental Program, Nairobi, Kenya \\ ${ }^{8}$ World Agroforestry Centre (ICRAF) China Programme, Beijing, China \\ ${ }^{9}$ Carbon Management and Sequestration Center, The Ohio State University, Columbus, OH 43210, USA \\ ${ }^{10}$ Agricultural and Biological Engineering Department, University of Florida, FL, USA \\ ${ }^{11}$ Helmholtz Centre for Environmental Research, Leipzig, Germany \\ ${ }^{12}$ School of Environmental Sciences and Development North West University (Potchefstroom Campus), Potchefstroom, South Africa \\ ${ }^{13}$ Secretariat DesertNet International (DNI), clo Biocentre Klein Flottbek and Botanical Garden, University of Hamburg, Germany
}

Received 23 February 2010; Revised 24 September 2010; Accepted 29 November 2010

\begin{abstract}
The United Nations Convention to Combat Desertification and its sister conventions, the United Nations Framework Convention on Climate Change and the Convention on Biological Diversity, all aim to halt or mitigate the deterioration of the ecological processes on which life depends. Sustainable land management (SLM) is fundamental to achieving the goals of all three Conventions. Changes in land management undertaken to address dryland degradation and desertification can simultaneously reduce net greenhouse gas emissions and contribute to conservation of biodiversity. Management to protect and enhance terrestrial carbon stocks, both in vegetation and soil, is of central importance to all three conventions. Protection of biodiversity conveys stability and resilience to agro-ecosystems and increases carbon storage potential of dryland systems. SLM improves livelihoods of communities dependent on the land. Despite these complementarities between the three environmental goals, tradeoffs often arise in their pursuit. The importance of human-environment interactions to the condition of land compels attention to adaptive management. In order to reconcile concerns and agendas at a higher strategic level, identification of synergies, conflicts, trade-offs, interconnections, feedbacks and spillover effects among multiple objectives, drivers, actions, policies and time horizons are crucial. Once these issues are transparent, coordinated action can be put into place across the three multilateral environmental agreements in the development of strategies and policy measures to support SLM. Copyright (C) 2011 John Wiley \& Sons, Ltd.
\end{abstract}

KEY WORDS: resilience; sustainable land management; desertification; land degradation; climate change; biodiversity

\section{INTRODUCTION}

The United Nations Convention to Combat Desertification (UNCCD) and its sister conventions, the United Nations Framework Convention on Climate Change (UNFCCC) and the Convention on Biological Diversity (CBD), agreed through the UN Conference on Environment and Development convened in Rio de Janeiro in 1992, all aim to halt deterioration of the ecological processes on which life depends. Management to protect and enhance terrestrial carbon stocks, both in vegetation and soil, is of central

* Correspondence to: A. L. Cowie, National Centre for Rural Greenhouse Gas Research, University of New England, Armidale, NSW, Australia.

E-mail: annette.cowie@une.edu.au importance to all three conventions. Despite complementarities between the three environmental goals, tradeoffs often arise in their pursuit. However, sustainable land management (SLM) is fundamental to achieving the goals of all three Conventions: changes in land management undertaken to address land degradation and desertification can simultaneously reduce net greenhouse gas emissions and contribute to conservation of biodiversity.

A consensus definition of SLM has proven elusive. Adapting the well-known definition of sustainable development devised by the World Commission on Environment and Development (UN, 1987) to the case of land, we consider SLM to be "the management of land to meet present needs without compromising the ability of future gener- 
ations to meet their own needs'. Resilience is an important complementary concept; following Walker and Salt (2006) we use the term here to describe the ability of an ecosystem to recover from, or to resist stresses (e.g. drought, flood, fire or disease). In order for ecosystems to continue to function under uncertain and changing conditions (and continue to supply services on which human communities depend), they must be resilient (Chapin et al., 2010). A major objective of SLM is, therefore, to impart resilience to agro-ecological systems.

This paper explores the connections among the issues tackled by the three conventions. It describes fundamental processes affecting resilience of human-environment systems in the drylands. It explores scientific opportunities for integrated implementation of monitoring and assessment under the three conventions, focusing on those facets affected by land management.

\section{LINKAGES AMONG CLIMATE CHANGE, DESERTIFICATION AND LOSS OF BIODIVERSITY}

The interconnections between dryland degradation and climate change are intimate and numerous (see also Chasek et al., 2011). Dryland degradation exacerbates and may itself be exacerbated by climate change. Feedback effects reverberate: dryland degradation depletes carbon stocks in vegetation and soils, increasing atmospheric carbon dioxide, and climate change is likely to increase temperatures and decrease rainfall in some regions, such as southern Africa (Boko et al., 2007). Deforestation and desertification result in major changes in land surface characteristics, and thus the energy balance at the Earth's surface, influencing climate over large areas (Sampaio et al., 2007).

Climate change is predicted to have direct and indirect effects on biodiversity (e.g. Theurillat and Guisan, 2001; Hughes, 2003; Meynecke, 2004). Indirect changes include shifts in the timing of reproduction and the size of the reproductive output (Forchhammer et al., 1998; Crick and Sparks, 1999; Winkler et al., 2002), changes in the availability and suitability of habitat resources (Visser and Both, 2005), differing habitat use, e.g. nest and shelter site selection (Telemeco et al., 2009) and altered survival rates (Chamaille-Jammes et al., 2006). Climate change will directly affect the distribution of species by shifting the location of climates to which they are adapted (Meynecke, 2004; Penman et al., 2010). Thus, climate change will present significant challenges to those whose livelihood depends directly or indirectly on biodiversity.

Carbon is a key linchpin between the UNCCD and UNFCCC. Soil carbon has a critical role in the drylands as a fundamental driver of ecosystem services such as plant production, and contributes to increasing resilience to climate variability and change. At the same time, the soil- vegetation system is a substantial carbon reservoir that can have large impacts, either positive or negative, on global warming. Globally, the soil stores $1550 \mathrm{Pg}$ of organic carbon, compared with $560 \mathrm{Pg}$ in vegetation and $780 \mathrm{Pg}$ in the atmosphere (Lal, 2004). Increases in the quantity of carbon stored in soil and vegetation will help to mitigate climate change. Conversely, the release of soil carbon into the atmosphere through land clearing, for example, will substantially aggravate global warming.

Water constitutes another important nexus for interaction between biophysical processes of interest to the UNCCD and UNFCCC. Increased water stress is predicted as a result of climate change in many drylands, thus management of water resources is a key issue in climate change adaptation (CAA, 2007). Land use change and land management affect water supply for all sectors. Boosting soil carbon enhances infiltration and moisture retention, improving water availability on site. The linkage between land degradation, SLM and water resources is most relevant, and most appropriately managed, at catchment scale.

Just as the impacts of these environmental problems are closely intertwined, their underlying causes are also closely related. While the major cause of climate change is the combustion of fossil fuels, the land use sector makes a significant contribution, particularly through deforestation and loss of soil carbon due to cultivation and overgrazing. Dryland degradation also results from practices such as overcultivation, overgrazing, deforestation, and poor irrigation practices, that directly or indirectly lead to loss of vegetation and declining soil quality. These same land management practices reduce biodiversity and ecosystem function through loss of habitat both on agricultural land such as through land-clearing, and in conservation areas due to indirect effects, such as through salinisation of catchments (Hodgson et al., 2004; CAA, 2007). The impacts can be distant from the cause, such as in downstream coastal areas, where eutrophication and silt accumulation can cause hypoxic 'dead zones' (Linton and Warner, 2003).

\section{Integrating Role of Soil Carbon}

Carbon plays a central role as an integrating factor in processes leading to, and management of, climate change, desertification and biodiversity loss (Lal, 2004). Soil organic carbon is derived from organic matter inputs, largely from leaf litter and root decay. Soil carbon stocks reflect the balance between organic matter inputs and losses due to decomposition through action of soil fauna and microbes and physical export by leaching and erosion (Schimel et al., 1994). Because plant productivity, and therefore organic matter inputs to soil, are limited by moisture stress, carbon stocks in dryland soils tend to be around half that of soils in moist environments in the same temperature regime (IPCC, 2006, p. 2.31). 
Soil carbon declines when rate of inputs is reduced and/or rate of loss is enhanced. Land management practices that reduce inputs include deforestation, conversion from perennial to annual plant species, and heavy grazing. Regularly cultivated soils have low soil carbon, partly as a result of disturbance of soil aggregates, enhancing decomposition, but also due to disruption of plant growth which reduces organic inputs (Cowie et al., 2006). Loss of soil productivity due to erosion of fertile topsoil or soil salinisation reduces plant production and thus reduces organic matter inputs into the soil. The fragile microbiotic, or cryptogamic, crust comprised of lichens, liverworts, mosses, algae, cyanobacteria, bacteria and fungi that develops on soils that have been undisturbed by cultivation or heavy grazing, plays a critical role in stabilising the surface of dryland soils against wind and water erosion (Eldridge and Greene, 1994). It also contributes significantly to nitrogen input and nutrient conservation (Eldridge and Greene, 1994), and contributes carbon to the soil organic matter pool (Beymer and Klopatek, 1991).

Soil organic matter is a fundamental determinant of soil chemical fertility, contributing to nutrient retention and nutrient cycling, and buffering against adverse chemical impacts (Brady and Weil, 2008). Soil physical attributes are strongly affected by soil organic matter: it retains moisture, and stabilises soil aggregates, facilitating aeration, root penetration and water infiltration, and reducing susceptibility to erosion. Thirdly, soil organic matter enhances biological activity in the soil, important to nutrient cycling and plant health (Uphoff et al., 2006). The cycling of carbon through biomass is at the core of provision of ecosystem services vital to human existence and thus to sustainable human-environment systems.

The coupled cycling of carbon, nitrogen and water, and other nutrients (e.g. phosphorus and sulphur), governs numerous ecosystem processes, including carbon sequestration in soil and vegetation. These coupled cycles, especially of carbon and water, are drastically perturbed and severely constrained by dryland degradation. Thus, minimising losses of water from the ecosystem and enhancing nutrient pools are important to increasing net primary production, reversing desertification and restoring degraded ecosystems (Tongway and Ludwig, 1996).

Above- and below-ground organisms play central roles in carbon cycling; functional diversity is critical in that these cycles require numerous interacting species. For example, diversity of vegetation promotes diversity of carbon inputs below ground, while carbon resource heterogeneity in the soil subsequently supports belowground biodiversity (Coleman and Whitman, 2005). Expanding functional biodiversity therefore extends the tolerance range of the suite of organisms responsible for the ecosystem services of soil formation, nutrient cycling, and water management, im- parting stability and resilience to the ecosystem (Ekschmitt and Griffiths, 1998; Moreira et al., 2008).

There is much speculation about the potential loss of soil carbon as climate change causes temperatures to rise, increasing microbial respiration rate and thus the rate of breakdown of organic matter (Fang et al., 2005; Knorr et al., 2005; Davidson and Janssens, 2006). The potential for positive feedback, whereby increased temperatures lead to loss of soil carbon, increasing atmospheric carbon dioxide, thus further increasing temperature, is considered a serious threat to stabilisation of Earth's climate (Kirschbaum, 2006; Heimann and Reichstein, 2008).

\section{SUSTAINABILITY AND RESILIENCE IN THE DRYLANDS}

The 'ecosystem stewardship' approach proposed by Chapin et al. (2010) integrates three strategies for sustainability: reducing vulnerability to expected changes; fostering resilience to sustain desirable conditions in the face of perturbations and uncertainty; and transforming from undesirable trajectories when opportunities emerge. Each of these is applicable to SLM in the drylands.

Dryland environments are characterised by cycles of change: rainfall is characteristically variable, and drought and wildfire are common. Productive dryland landscapes rely on spatial redistribution and concentration of water and nutrients to achieve zones of sufficient water availability and fertility to support growth of vascular plants (Tongway and Ludwig, 2005). Resource redistribution also occurs temporally: disturbances such as fires and floods release and redistribute nutrients, and suppress dominating vegetation species, creating opportunities for colonising species. The spatial and temporal diversity in vegetation community structure and species thus created supports a diversity of fauna and microorganisms. This diversity of function, especially if combined with diversity of response to stresses amongst the organisms engaged in each function, imparts resilience to the ecosystem (Walker and Salt, 2006). Tilman and Downing (1994) showed that net primary production in more diverse plant communities is more resilient to drought. In the Sahelian Butana Region in the eastern Republic of Sudan, the semi-sedentary Shukriya nomads lamented the loss of perennial species, such as Blepharis edulis (Arabic: siha), whose biomass and nutritive values were of special importance during the dry season when annual species withered away (Akhtar, 1994). Successful households in these environments are those that are able to diversify economic activities, to exploit different ecological niches and economic opportunities such as new markets (Mazzucato and Niemeijer, 2000). Transhumant and nomadic livestock systems that respond to the temporal and spatial variation in pasture quality and quantity across 
dryland environments achieve higher productivity than sedentary systems (de Jode, 2010).

Resilient ecosystems are the building blocks of sustainable, productive agro-ecosystems. However, the natural cycles of productive, resilient dryland systems clash with many modern land use systems, which strive for simplicity, uniformity and predictability. When thresholds are crossed and regime shifts occur it is often a result of human actions. For example, overgrazing leads to erosion of topsoil, exposing subsoil of low fertility and structural stability. The soil surface consequently crusts and seals, preventing infiltration. Plants fail to establish in dry infertile soil, so the site cannot be recolonised, and productivity is dramatically reduced.

The problems of dryland degradation, climate change and biodiversity loss, along with issues such as resource depletion, pollution, and urban expansion into productive farmland are symptomatic of society's general lack of understanding of natural processes. Land management systems that protect topsoil, conserve and recycle nutrients, conserve and concentrate water are those that will maintain productivity in the drylands and simultaneously advance the objectives of all three Conventions (Cowie et al., 2007). SLM frameworks that connect the conventions should follow integrated systems approaches combined with learning-oriented, adaptive forms of management and governance, recognising that simple prescriptive responses are unlikely to be effective in managing complex, variable human-environment systems (see also Reed et al., 2011 and Reynolds et al., 2011). 'Adaptive management' refers to the capacity of the actors in the system to adjust, reform and reorient in response to new insights, thereby promoting ecological and socio-economic resilience (Beddoe et al., 2009). The CBD, through the Addis Ababa Principles and Guidelines for the Sustainable Use of Biodiversity (CBD, 2004), advocates adaptive management for sustainable use of native species. Governance approaches also require adaptive capacity; recognising that dryland systems are unpredictably variable, management must be able to withstand and adjust to shocks. The need for adaptive capacity is reflected in Principle \#1 of the Dryland Development Paradigm (Reynolds et al., 2007, 2011), which stresses the dynamic, co-adapting nature of coupled human-environment systems in the dryland ecozone. Adaptive capacity facilitates smooth transitions to new desirable regimes.

\section{THE ROLE OF SLM IN ADDRESSING THE GOALS OF THE UNFCCC, UNCCD AND CBD}

\section{Climate Change and SLM}

The goal of the UNFCCC is to stabilise greenhouse gas emissions 'at a level that would prevent dangerous anthropogenic interference with the climate system'. The Kyoto Protocol allows parties to offset emissions from other sectors with removal credits generated through SLM practices such as afforestation and reforestation, cropland management, grazing land management and revegetation. Under the Clean Development Mechanism, Annex I Parties ${ }^{1}$ can offset emissions through projects implemented in developing countries. Afforestation and reforestation projects are eligible under the Clean Development Mechanism, though other land management measures are not.

\section{Climate Change and Soil Carbon}

The role of SLM in protection and enhancement of soil organic carbon is a particular area of synergy between the UNFCCC and UNCCD. The UNCCD recognises the value of soil carbon as a key contributor to soil quality and productivity: it recommends that parties report above and below-ground carbon stocks as one of 11 priority indicators for monitoring desertification (UNCCD, 2009).

It is often hypothesised that, because many dryland soils are carbon-depleted, the vast area of drylands can serve as an important sink for atmospheric carbon dioxide (e.g. Suleimenov and Thomas, 2007; Vågen et al., 2005). In reality, sequestration will be limited by factors including low net primary productivity in the drylands; limited ability to stabilise organic matter in soils low in soil carbon (Kimetu et al., 2009); and the nutrient costs of storing carbon in soils due to the simultaneous sequestration of nitrogen, phosphorus and potassium as the soil organic pool increases (Lal, 2004). Nevertheless, success in rehabilitation of semiarid regions, leading to significant increase in soil carbon has been demonstrated (Tongway and Ludwig, 1996.) The technical sink potential through land management is estimated at $0.3-0.5 \mathrm{Pg}$ C/year for desertification control (Lal et al., 1999) and 0.4-1.0 Pg C/year for reclaiming saltaffected soils (Lal, 2010).

Practices that are encouraged for SLM and that also build soil carbon include measures that contribute additional organic matter to the soil (stubble retention, cover crops, green manure crops, application of compost, controlled grazing, application of fertiliser, lime or gypsum to correct nutrient deficiencies, acidity or sodicity) and measures that reduce loss of organic matter, such as zero tillage, contour terracing and integrated crop-livestock-forestry systems. Converting organic carbon to biochar to be used as a soil amendment may benefit SLM in the drylands, and contribute simultaneously to climate change mitigation (Lehmann and Joseph, 2009a). While it is recognised that biomass supplies are limited in the drylands, replacing traditional stoves with biochar-producing stoves can increase efficiency of fuel use

\footnotetext{
${ }^{1}$ Industrialised nations and those with 'economies in transition'.
} 
for energy, and supply biochar for soil amendment simultaneously (Lehmann and Joseph, 2009b). Further testing of biochar in dryland systems and life cycle assessments are needed to determine the net impacts of introducing biochar as a soil amendment when it is produced as a by-product of a broader bioenergy initiative (Roberts et al., 2010).

Soil carbon management in cropland and grazing land were recognised as eligible mitigation actions under the Kyoto Protocol, ${ }^{2}$ but very few Parties to the UNFCCC elected to include these activities in their accounts for the first commitment period. Changes under a future climate change agreement may increase the attractiveness of this option, thus facilitating participation in project-level emissions trading by landholders, providing a financial incentive to encourage the widespread and rapid adoption of SLM, contributing simultaneously to the urgent tasks of addressing climate change and combating dryland degradation. Mitigation through soil carbon management is considered one of the most cost-effective mitigation options (McKinsey, 2009; Al-Juaied and Whitmore, 2009).

Future agreement under the UNFCCC is foreshadowed to include Nationally Appropriate Mitigation Actions (NAMAs), as an avenue to facilitate participation by nonAnnex I Parties (UNFCCC, 2007). There is much support for inclusion of soil carbon management in agricultural lands as an eligible mitigation action for a post-2012 agreement, particularly for non-Annex I Parties, possibly through NAMAs (e.g. Streck et al., 2010). This could mobilise funding to support SLM at a sectoral rather than project level, which would overcome some of the barriers to projectbased approaches to carbon crediting in the agriculture sector (FAO, 2009).

\section{Adaptation to Climate Change}

Adaptation measures will be required at regional and local levels to reduce the adverse impacts of inevitable climate change, regardless of the scale of climate change mitigation undertaken over the next two or three decades. SLM practices that protect soil organic matter, maintain vegetative cover and conserve biodiversity are vital to improving resilience and capacity to adapt to the anticipated impacts of climate change. Recognising that Least Developed Countries are particularly vulnerable to climate change and have very limited adaptive capacity, the UNFCCC (decision 5/CP.7) agreed to provide financial support to Least Developed Countries, the majority of which are affected by dryland degradation, for development of National Adaptation Programmes of Action (NAPAs; UNFCCC, 2009b).

\footnotetext{
${ }^{2}$ Under Article 3.4, applying to Annex 1 countries, but not under the CDM.
}

\section{BIODIVERSITY AND SLM}

The CBD identifies the following land use and land management practices as pressures that impact on biodiversity in dry and sub-humid lands (CBD, 2008):

- Habitat conversion (e.g. land clearing for agriculture; Holt et al., 1999; Losos and Schluter, 2000).

- Over-grazing, which reduces diversity and can increase the density of alien/invasive species (Henderson and Keith, 2002; Keeley et al., 2003; Tasker and Bradstock, 2006).

- Introduced species, often causing the extinction of native species or drastically altering community structure (Savidge, 1987; Holdaway, 1999; Matarczyk et al., 2002; Downey et al., 2009).

- Change to natural fire regimes, such as through fires suppression or managed burning, which inadvertently changes vegetation composition and structure and as a consequence affects faunal community composition (Keith, 1996; Andersen et al. 2005; Penman et al. 2008).

- Changes in hydrological flows and balances through regulation and diversion for domestic, agricultural and power generation purposes, reducing diversity of fauna and flora and often causing salinity problems (e.g. Kingsford, 2000; Cramer and Hobbs, 2002).

- Overharvesting of species, which can lead to ecosystem collapse (Novacek and Cleland, 2001; De Roos and Persson, 2002).

- Soil management practices (fertiliser application, cultivation, fallowing and crop rotations). For example, changes in nutrient balance can affect species composition and may reduce the diversity of soil microbial communities (McLaughlin and Mineau, 1995; Grevilliot et al., 1998) and the flora/fauna that rely on the ecosystem services that microbes provide; eutrophication of downstream waterways and nutrient enrichment of conservation areas can have detrimental consequences for aquatic and terrestrial biodiversity.

- Cultivation of fewer and more genetically uniform crop species, due to influence of agribusiness and market demands, which reduces the diversity of agro-ecosystems.

SLM practices counteract the negative impacts on biodiversity of the management actions listed above. They increase the diversity of production species and systems, reducing vulnerability to pests, diseases, and climatic variation, and enhance soil microbial diversity. SLM at landscape scale protects native habitat remnants needed by pollinators and biological control agents. SLM also reduces the use of pesticides and chemical fertilisers which are harmful to many species. SLM promotes agricultural systems that mimic natural systems in order to maintain ecosystem function and may include the sustainable harvest 
of native species, generating value that motivates the conservation of these species. These measures are congruent with strategies of the $\mathrm{CBD}$, viz., to conserve production species and minimise adverse impacts on surrounding ecosystems. The CBD recognises that conservation and restoration of the physical and chemical interactions within the environment, and relationships between species and the abiotic environment, "is of greater significance for the longterm maintenance of biological diversity than simply protection of species' (Principle 5 of the Ecosystem Approach, CBD, 2000). Thus there are strong complementarities between the goals of the CBD and SLM practices.

\section{MULTIPLE BENEFITS OF SLM}

Ecosystem services delivered by agricultural systems can include provisioning services (provision of food, feed, fibre and fuel), regulating services (regulation of climate, water quality and quantity; regulation of populations of pollinators, pests, pathogens, wildlife; nutrient cycling) and cultural services (aesthetics, spiritual services and recreation) (MA, 2005). Studies that have sought to quantify the economic value of market and non-market services from alternative land uses have demonstrated that while sustainably managed systems may have lower market value, they commonly have greater total value when non-market ecosystem services are included (MA, 2005). Greater biological diversity, promoted by SLM, contributes to this higher value. For example, Sandhu et al. (2008) determined that the value of ecosystem services was greater under organic than conventional farming methods. Physical protection of crops and biological control of pests, arising from the use of shelterbelts and avoidance of pesticides, which enhance biological diversity, contributed to the higher value of ecosystem services in organic farms. Similarly, Porter et al. (2009) estimated the total market value and non-market value of the services from pastures, croplands and mixed biomass/crop/pasture systems and demonstrated that biodiverse mixed systems had higher ecosystem service values than cropland.

\section{SLM and Alleviation of Poverty}

All three conventions recognise the need for sustainable development, to provide a livelihood to communities dependent on the land. The UNCCD enunciates alleviation of poverty as a core objective, acknowledging that impoverished communities have little capacity to respond to environmental challenges. SLM practices have the potential to simultaneously deliver environmental benefits and improved livelihoods: in their review of the impacts of agricultural practices across a wide range of agro-ecological regions and farming systems in developing countries, Pretty et al. (2006) found increased productivity where sustainable practices, including conservation tillage, water conservation, agroforestry, integrated pest management, and integration of livestock into farming systems, were implemented. Besides higher yields, sustainable systems had higher water use efficiency, and lower costs (in terms of fertiliser and pesticide inputs) than conventional practice (Pretty et al., 2006). Thus, SLM can enhance food security and rural incomes. However, specific conservation farming practices are not all universally applicable, and local solutions to SLM have not yet been sufficiently developed for all situations (Giller et al., 2009).

\section{SYNERGIES AND TRADEOFFS IN ADDRESSING THE GOALS OF THE CONVENTIONS}

SLM practices that conserve moisture, maintain or enhance species diversity such as conservative grazing, reduced cultivation, retention of crop residues, replacement of annual with perennial species, use of mulches and green manures, reforestation and revegetation to create windbreaks and shelter belts, and utilisation of native species, simultaneously and synergistically contribute to the objectives of the three conventions (Cowie et al. 2007). Furthermore, SLM practices enhance productivity and nutrient and water use efficiency, thus contributing to the UN Millennium Development Goals of reducing hunger and alleviating poverty.

However, while there are synergies among the objectives of the Conventions, tradeoffs must also be acknowledged. Optimisation for one objective can reduce outcomes for the others: for example, a monoculture of an exotic plantation species may produce the greatest carbon sequestration rate, but will clearly have reduced biodiversity value compared with revegetation with mixed form native species. Density of shrubs and trees is increasing in many semi-arid areas (with introduced species, e.g. Acacia nilotica in northern Australia, Prosopis juliflora in Kenya's drylands, Mimosa pigra in Zambia's Lochinvar National Park; and with native species, e.g. Callitris glaucophylla in New South Wales, Australia, and Acacia mellifera in Namibia). This shrub encroachment reduces grass cover, which may increase susceptibility to erosion if stocking rates are not reduced, and can affect soil condition through acidification (Tighe et al., 2009), reduce biodiversity (Ayers et al., 2001; Genovesi, 2009), and reduce grazing value and thus economic returns. However, it sequesters carbon (McHenry et al., 2006), contributing to climate change mitigation. One possible integrated approach for the drylands could be to harvest invasive species as a feedstock for local bioenergy initiatives, with biochar as a valuable by-product. After a few cycles of regrowth and harvest for bioenergy and biochar production the climate change mitigation value would be greater than the potential carbon storage in the 
vegetation. This approach would enhance grazing value of the land, and assist in management of biodiversity loss and soil erosion due to loss of understorey species caused by bush encroachment. The risk of environmental and health impacts through release of methane and particulates from biochar production facilities (Downie et al., in press) could be managed through promotion of systems that control smoke and capture methane. Care is also needed to avoid environmental and productivity risks potentially associated with biochar (Downie et al., in press) or bioenergy production if biomass is supplied from unsustainable sources (e.g. crop stubbles required for erosion control and moisture retention, or primary forest).

\section{POTENTIAL FOR A COMMON APPROACH TO MONITORING AND ASSESSMENT}

The three conventions acknowledge the interactions between environmental issues, and consequent need to simultaneously address each of their goals. Chasek et al. (2011) discuss the activities that have been undertaken to achieve coordination in implementation of the conventions. This is important as a lack of coordination could lead to duplication of effort and competition for resources. Coordinated action between the conventions can optimise outcomes, and could increase efficiency of monitoring and reporting, thus reducing total costs of pursuing these goals (Chasek et al., 2011).

\section{SLM IN UNCCD MONITORING AND REPORTING}

The UNCCD's 10-Year Strategy (2008-2018) includes a global hierarchical framework of Strategic Objectives, Expected Impacts, and Indicators intended to guide monitoring and assessment (UNCCD, 2007). Nationallyand regionally relevant indicators are to be developed for reporting the implementation of the 10-Year Strategy (UNCCD, 2007). Numerous framework elements reflect SLM objectives. Strategic Objective 3 is specifically geared towards strengthening the connections to sister Convention topics; its expected impact 3.1 is 'SLM and combating desertification/land degradation contribute to the conservation and sustainable use of biodiversity and the mitigation of climate change'. Connections between UNCCD and CBD indicators, as mapped by the 2010 Biodiversity Indicators Partnership (2010 BIP, 2009), are shown in Table 1, and discussed further below.

\section{SLM IN UNFCCC MONITORING AND REPORTING}

The Intergovernmental Panel on Climate Change (IPCC) has developed internationally agreed methodologies that parties use to estimate greenhouse gas emissions and removals to report to the UNFCCC (Houghton et al., 1997; Penman et al., 2003; IPCC, 2006). The 2006 inventory guidelines include, inter alia, a volume on Agriculture, Forestry and Other Land Use which describes methodologies for estimating greenhouse gas emissions and removals where changes in land use or land management practice have occurred. The methodologies for estimating carbon stock changes in soil and woody vegetation through practices such as cropland management, grazing land management and revegetation are applicable to monitoring aspects of SLM.

The future (post-2012) climate change agreement is currently being negotiated. It is expected to include provision for NAMAs and sectoral approaches in implementation and accounting for mitigation actions. Sectoral implementation of SLM would overcome some of the barriers to participation of smallholders in project-level mechanisms. Monitoring the impact of sectoral approaches will require national greenhouse gas inventories for the land use sector, and where NAMAs are internationally supported, at least minimum levels of monitoring and reporting (FAO, 2009). Approaches for sectoral accounting in agriculture could learn from approaches being developed for Reducing Emissions from Deforestation and Forest Degradation in Developing Countries (REDD; UNFCCC, 2009a).

Climate change takes place in a unitary system because greenhouse gases mix in the atmosphere, whereas land management is locally expressed and therefore highly diverse. Accordingly, IPCC has a global focus, while dryland degradation research has emphasised the local and regional scales. The link between land use change and climate feedbacks was not emphasised in the IPCC's Fourth Assessment, but future assessments at regional scales are expected to consider SLM-climate interactions.

\section{SLM IN CBD MONITORING AND REPORTING}

The 2010 Biodiversity Indicators Partnership (2010 BIP, 2009, http://www.twentyten.net) is a global initiative to monitor progress towards the CBD indicators. It also seeks to help update those indicators as part of the CBD strategic planning process, including the harmonisation of those biodiversity indicators between the three Conventions. The 2010 Biodiversity Indicators Partnership proposed a harmonisation framework at the UNCCD First Scientific Conference, reproduced in Table 1 (2010 BIP, 2009) that forms a basis for further collaboration. CBD indicators shown in bold in Table 1 are those that we have identified as particularly relevant to SLM. The CBD has recognised that its current suite of indicators does not adequately assess SLM, dryland degradation and agricultural biodiversity, especially with respect to diversity of species, breeds and varieties (Secretariat of the CBD, 2004). The UNCCD could work with the CBD through the Biodiversity Indicators 
SCIENTIFIC CONNECTIONS IN MONITORING

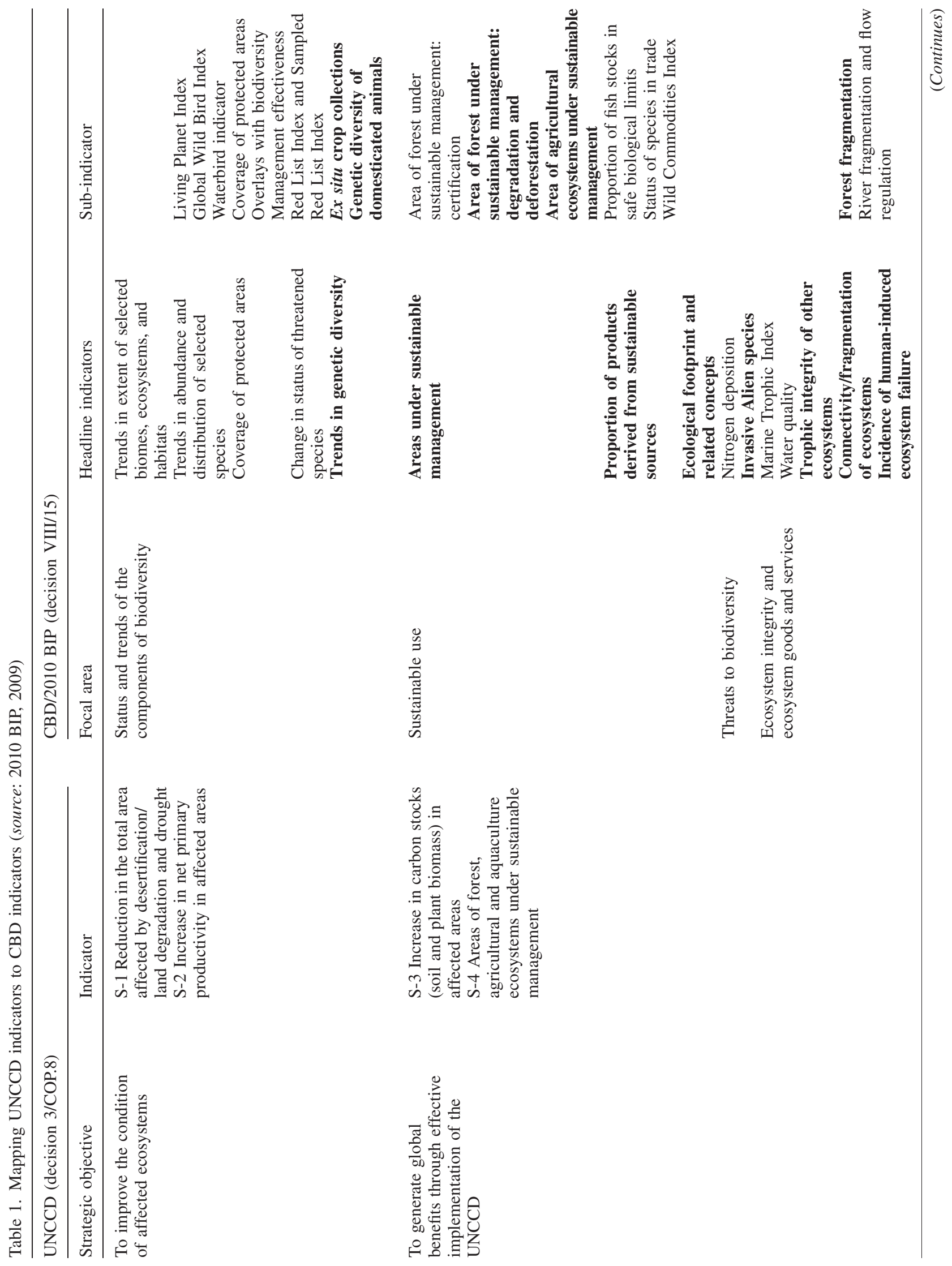

Copyright (C) 2011 John Wiley \& Sons, Ltd. 


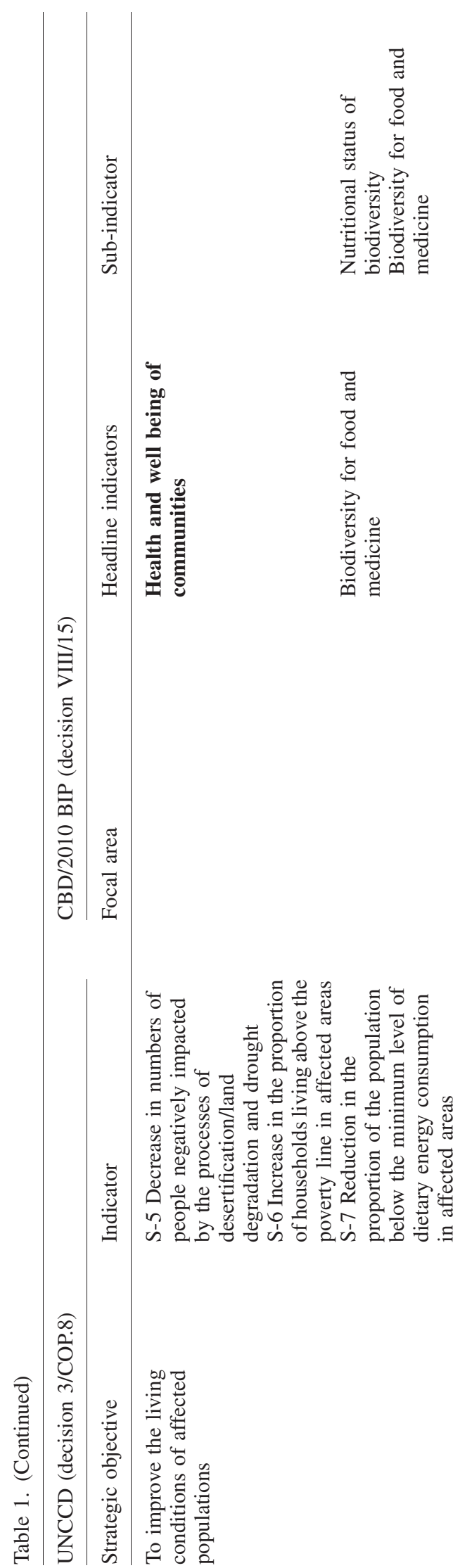

Copyright (C) 2011 John Wiley \& Sons, Ltd.
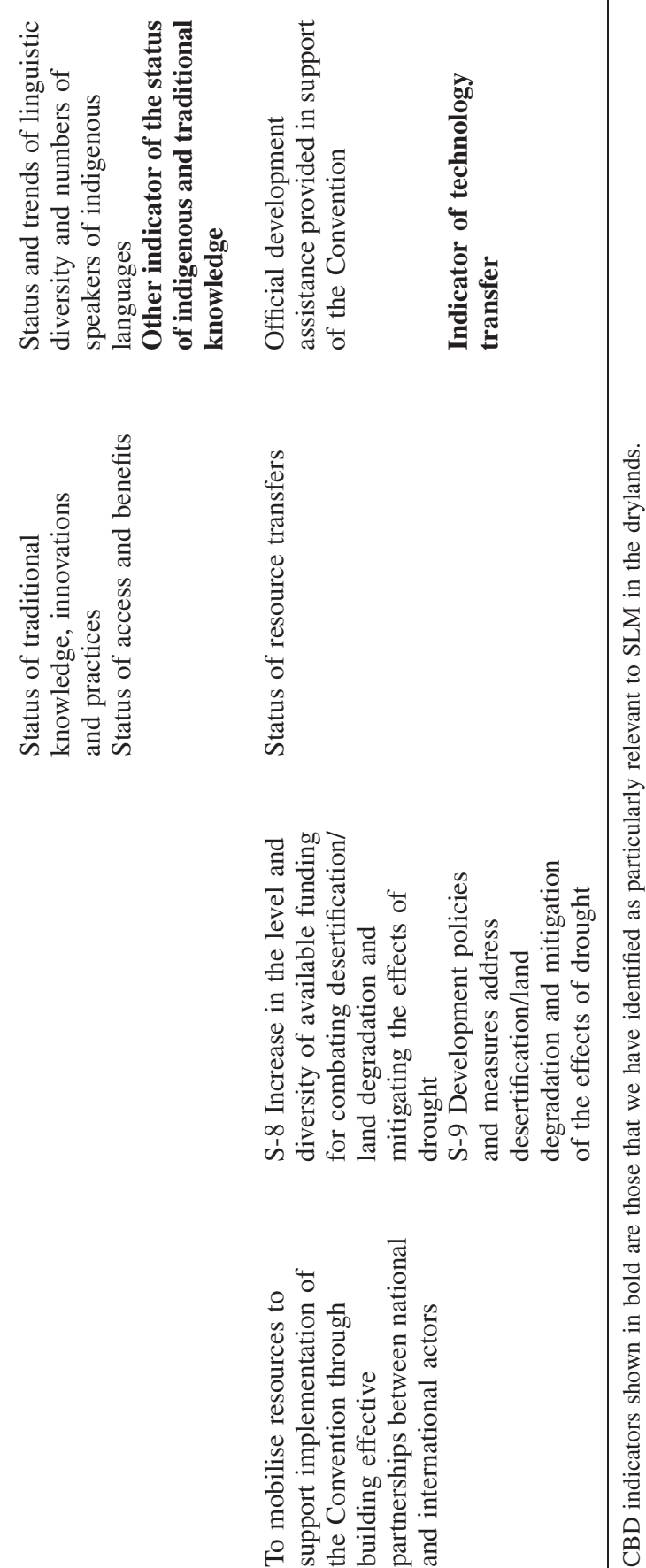

LAND DEGRADATION \& DEVELOPMENT, 22: 248-260 (2011) 
Partnership to address these areas of recognised deficiency, specifically in identifying indicators that assess the underpinning processes of ecological function, and the identification of tipping points (Leadley et al. 2010).

\section{Future Development of Indicators for Monitoring Dryland Degradation, Climate Change and Biodiversity}

In earlier sections, we identified the following as critical to sustainability and resilience in the drylands: conservation of water and nutrient resources; protection and enhancement of soil carbon; maintenance of diversity in agricultural systems; and implementation of an adaptive management framework.

The UNCCD indicator framework (left hand side of Table 1) addresses some of the fundamental aspects of SLM in the drylands. The critical and integrative factor soil carbon is included in S-3. Indicators S-1, S-2 and S-3 assess trends in condition of physical resources, while indicators S-5, S-6 and S-7 consider the condition of affected populations. Measures of response are also included: S-4 addresses directly the area managed under sustainable practices, while S-8 and S-9 assess the existence of supportive policies.

The aspects of resource conservation, and maintenance of genetic, structural, spatial and functional diversity, could be addressed through national and regionally-relevant indicators for S-4. Similarly, S-9 could include recognition of adaptive management. It is important that these drivers of resilience are factored in when local indicators are developed.

Having identified indicators, data must then be located or generated. Remote sensing is a viable tool for assessing resource condition in the drylands. For example, the 'Pastures from Space' program is used in Australia to predict pasture growth using MODIS satellite imagery (Smith et al., in press). Applications of remote sensing for monitoring dryland degradation are discussed by Buenemann et al. (2011).

A critical element identified above that should be considered in development of indicators is vulnerability. Attention should be given to development of indicators relevant to underpinning processes of ecological function, and identification of tipping points, acknowledging that the latter are situation-specific, and require sound process-level understanding. For example, in the case of soil carbon, it may be enlightening to utilise, in addition to total organic carbon, more sensitive measures that discriminate between the stable and labile fractions, which would indicate the vulnerability of soil carbon stocks. Quick, cheap methods based on mid-infra red spectroscopy (Janik et al., 2007) could be applied, particularly if future technological development allows in situ measurement.

Process-based models, in combination with remotelysensed data, will be a valuable tool for monitoring condition with respect to critical thresholds. Sustainability of grazing in Australian rangelands has been assessed by Carter et al. (2007) through modelled estimates of pasture growth and utilisation, based on climate data, fire events and stocking rates.

Vulnerability of human populations, while undoubtedly complex, can be quantified, for example, through rural livelihoods analysis (Ellis, 2000). Using a combination of measures of human, social, natural, physical and financial capital Nelson et al. (2010) applied a composite index of adaptive capacity to assess the vulnerability of rural communities in Australia.

Future development of the UNCCD framework should focus on mechanistic connections between indicators. If linkages between, e.g. soil properties and livelihoods are better quantified, indicators of soil condition may aid in addressing sustainability constraints more effectively.

There are substantial opportunities for mutual benefit by connecting local and global perspectives, for example by developing accounting approaches for project-level SLM interventions, as is being done by the Carbon Benefits Project (GEF, 2010). Further development of practice- or activity-based monitoring approaches to accounting for benefits from adoption of SLM practices (e.g. Woelke and Tennigkeit, 2009) have potential to link the monitoring of climate change mitigation and adaptation with the information needs of other conventions.

\section{CONCLUSION}

The linkages between the goals and actions of the UNFCCC, CBD and UNCCD are numerous and the benefits from tackling these environmental issues in concert are many, as are the risks in focusing on one area alone. Carbon is an integrating factor: maintenance or enhancement of carbon in vegetation and soil contributes to climate change mitigation and reduced dryland degradation, and can enhance biodiversity.

Process-level understanding of the human-environment interactions underpinning dryland agro-ecosystems is fundamental to identifying effective management approaches to simultaneously tackle the objectives of the three conventions. The following must be recognised in developing monitoring and assessment strategies for dryland systems:

(1) An optimum stable state is not an achievable goal because dryland systems are dynamic; cycles of change are a natural feature of the drylands, where rainfall is characteristically variable and drought is common.

(2) Resilience is critical to sustainability in this dynamic environment, and is fostered by preservation of diversity and redundancy; a focus on maximising production in 
the short term reduces resilience and strains ecosystem integrity.

(3) Monitoring and assessment strategies should be cognisant of nonlinearities in ecosystem responses, especially thresholds that signify potential system collapse; management must be responsive to monitoring, and ready to intervene to maintain ecosystem function and productivity.

SLM promotes management practices that mitigate dryland degradation, climate change and biodiversity loss, though there are inevitable tradeoffs in that outcomes cannot always be maximised for all three objectives, especially in the short term. Key attributes of SLM to be monitored are: conservation and effective use of water and nutrient resources; maintenance and, wherever possible, augmentation of soil organic matter; preservation of diversity in land use and agricultural production species; and implementation of an adaptive management framework. There is considerable potential to combine effort and resources to build capacity for monitoring and assessment of SLM under the three conventions.

\section{REFERENCES}

2010 BIP. 2009. Lessons from the global CBD biodiversity indicators process Biodiversity Indicators partnership. http://www.twentyten.net/ posters.

Akhtar M. 1994. Geo-ecosystems and pastoral degradaton in the Butana. Animal Research and Development 39: 17-26 (Institute for Scientific Cooperation, Tuebingen, Federal Republic of Germany).

Al-Juaied M, Whitmore A. 2009. Realistic Cost of Carbon Capture. J.F. Kennedy School of Government: Harvard, MA.

Andersen AN, Cook GD, Corbett LK, Douglas MM, Eager RW, RussellSmith J, Setterfield SA, Williams RJ, Woinarski JCZ. 2005. Fire frequency and biodiversity conservation in Australian tropical savannas: implications from the Kapalga fire experiment. Australian Ecology 30: 155-167.

Ayers D, Melville G, Szigethy-Gyula J, Read D, Rees R, Atkinson A. 2001. Woody Weeds and Biodiversity in Western New South Wales. National Capital Printing: Canberra.

Beddoe R, Costanza R, Farley J, Garza E, Kent J, Kubiszewski I, Martinez L, McCowen T, Murphy K, Myers N, Ogden Z, Stapleton K, Woodward J. 2009. Overcoming systemic roadblocks to sustainability: the evolutionary redesign of worldviews, institutions and technologies. Proceedings of the National Academy of Sciences of the United States of America 106: 2483-2489.

Beymer RJ, Klopatek JM. 1991. Potential contribution of carbon by microphytic crusts in pinyon-juniper woodlands. Arid Land Research and Management 5: 187-198.

Boko M, Niang I, Nyong A, Vogel C, Githeko A, Medany M, Osman-Elasha B, Tabo R, Yanda P. 2007. Africa. In Climate Change 2007: Impacts, Adaptation and Vulnerability. Contribution of Working Group II to the Fourth Assessment Report of the Intergovernmental Panel on Climate Change, Parry ML, Canziani OF, Palutikof JP, van der Linden, PJ Hanson CE (eds). Cambridge University Press: Cambridge, UK; 433467.

Brady NC, Weil RR. 2008. The Nature and Properties of Soils. 14th Ed. Pearson/Prentice Hall: Upper Saddle River, New Jersey.

Buenemann M, Martius C, Jones JW, Herrmann SM, Klein D, Mulligan M, Reed MS, Winslow M, Washington-Allen RA, Lal R, Ojima D. 2011. Integrative geospatial approaches for the comprehensive monitoring and assessment of land management sustainability: rationale, potentials, and characteristics. Land Degradation \& Development 22: 226-239.

CAA (Comprehensive Assessment of Water Management in Agriculture). 2007. Water for Food, Water for Life: A Comprehensive Assessment of Water Management in Agriculture. Earthscan, London and International Water Management Institute: Colombo.

Carter J, Silcock R, Bastin G, Schliebs M. 2007. Australian Collaborative Rangeland Information System, Reporting Change in the Rangelands 2007 Queensland Information for the National Report ACRIS Rangelands 2007 - Taking the Pulse. http://www.environment.gov.au/land/ publications/acris/pubs/acris-qld-reporting-oct07.pdf.

CBD. 2000. Ecosystem approach COP 5 Decision V/6 Decisions adopted by the Conference of the Parties to the Convention on Biological Diversity at its Fifth Meeting.

CBD. 2004. Sustainable Use (Article 10) COP 7 Decision VII/12 Decisions adopted by the Conference of the Parties to the Convention on Biological Diversity at its Seventh Meeting.

CBD. 2008. Dry and Sub-humid Lands Biodiversity - What's the Problem? http://www.cbd.int/drylands/problem/.

Chamaille-Jammes S, Massot M, Aragon P, Clobert J. 2006. Global warming and positive fitness response in mountain populations of common lizards Lacerta vivipara. Global Change Biology 12: 392402.

Chapin FS, III, Carpenter R, Kofinas GP, Folke C, Abel N, Clark WC, Olsson P, Stafford Smith DM, Walker BH, Young OR, Berkes F, Biggs R, Grove JM, Naylor RL, Pinkerton E, Steffen W, Swanson FJ. 2010. Ecosystem stewardship: sustainability strategies for a rapidly changing planet. Trends in Ecology and Evolution 25: 241-249.

Chasek P, Essahli W, Akhtar-Schuster M, Stringer LC, Thomas R. 2011. Integrated land degradation monitoring and assessment: horizontal knowledge management at the national and international levels. Land Degradation \& Development 22: 272-284.

Coleman DC, Whitman WB. 2005. Linking species richness, biodiversity and ecosystem function in soil systems. Pedobiologia 49: 479-497.

Cowie AL, Smith P, Johnson D. 2006. Does soil carbon loss in biomass production systems negate the greenhouse benefits of bioenergy? Mitigation and Adaptation Strategies for Global Change 11: 979-1002.

Cowie AL, Schneider UA, Montanarella L. 2007. Potential synergies between existing multilateral environmental agreements in the implementation of land use, land-use change and forestry activities. Environmental Science and Policy 10: 335-352.

Cramer V, Hobbs R. 2002. Ecological consequences of altered hydrological regimes in fragmented ecosystems in southern Australia: impacts and possible management responses. Austral Ecology 27: 546-564.

Crick HQP, Sparks TH. 1999. Climate change related to egg-laying trends. Nature 399: 423-424.

Davidson EA, Janssens IA. 2006. Temperature sensitivity of soil carbon decomposition and feedbacks to climate change. Nature 440: 165-173.

de Jode H (ed.). 2010. Modern and Mobile. The Future of Livestock Production in Africa's Drylands. IIED and SOS: Sahel, London.

De Roos AM, Persson L. 2002. Size-dependent life-history traits promote catastrophic collapses of top predators. Proceedings of the National Academy of Sciences of the United States of America 99: 1290712912.

Downey PO, Williams MC, Whiffen LK, Turner PJ, Burley AL, Hamilton MA. 2009. Weeds and biodiversity conservation: a review of managing weeds under the New South Wales Threatened Species Conservation Act 1995. Ecological Management and Restoration 10: S53-S58.

Downie A, Munroe P, Cowie A, Van Zwieten L, Lau D. in press. Biochar as a geo-engineering climate solution: Hazard identification and risk management. Critical Reviews of Environmental Science and Technology. DOI: $10.1080 / 10643389.2010 .507980$.

Ekschmitt K, Griffiths BS. 1998. Soil biodiversity and its implications for ecosystem functioning in a heterogeneous and variable environment. Applied Soil ecology 10: 201-215.

Eldridge DJ, Greene RSB. 1994. Microbiotic soil crusts: a review of their roles in soil and ecological processes in the rangelands of Australia. Australian Journal of Soil Research 32: 389-415.

Ellis F. 2000. Rural Livelihoods and Diversity in Developing Countries. Oxford University Press: Oxford. 
Fang C, Smith P, Smith JU. 2005. Is resistant soil organic matter more sensitive to temperature than the labile organic matter? Biogeosciences Discuss 2: 725-735.

FAO. 2009. Food Security and Agricultural Mitigation in Developing Countries: Options for Capturing Synergies. FAO: Rome.

Forchhammer MC, Post E, Stenseth NC. 1998. Breeding phenology and climate change. Nature 391: 29-30.

GEF. 2010. Carbon Benefit Project offer innovative climate change solutions across complex landscapes global environment facility. http://www.thegef.org/gef/node/2263.

Genovesi P. 2009. Invasive alien species in a changing world. Biodiversity 10: $3-5$.

Giller K, Witter E, Corbeels M, Titonell P. 2009. Conservation agriculture and smallholder farming in Africa: the heretics' view. Field Crops Research 114: 23-34.

Grevilliot F, Krebs L, Muller S. 1998. Comparative importance and interference of hydrological conditions and soil nutrient gradients in floristic biodiversity in flood meadows. Biodiversity and Conservation 7: 14951520.

Heimann M, Reichstein M. 2008. Terrestrial ecosystem carbon dynamics and climate feedbacks. Nature 451: 289-292.

Henderson MK, Keith DA. 2002. Correlation of burning and grazing indicators with composition of woody understorey flora of dells in a temperate eucalypt forest. Austral Ecology 27: 121-131.

Hodgson G, Hatton T, Salama R. 2004. Modelling rising groundwater and the impacts of salinization on terrestrial remnant vegetation in the Blackwood Basin. Ecological Management and Restoration 5: 5260.

Holdaway RN. 1999. Introduced predators and avifaunal extinction. In Extinctions in Near Time. MacPhee RDE (ed.). Kluwer Academic/ Plenum Publishers: New York; 189-238.

Holt RD, Lawton JH, Polis GA, Martinez ND. 1999. Trophic rank and the species area relationship. Ecology 80: 1495-1504.

Houghton JT, Meira Filho LG, Lim B, Tréanton K, Mamaty I, Bonduki Y, Griggs DJ, Callander BA (eds). 1997. Revised 1996 IPCC Guidelines for National Greenhouse Gas Inventories. Intergovernmental Panel on Climate Change, Meteorological Office: Bracknell, UK; (Volume 1: Greenhouse gas inventory reporting instructions. $130 \mathrm{pp}$. Volume 2: Greenhouse gas inventory workbook. 346 pp. Volume 3: Greenhouse gas inventory reference manual. $482 \mathrm{pp}$ ).

Hughes L. 2003. Climate change and Australia: trends, projections and impacts. Austral Ecology 28: 423-443.

IPCC. 2006. 2006 IPCC Guidelines for National Greenhouse Gas Inventories (Prepared by the National Greenhouse Gas Inventories Programme). Eggleston HS, Buendia L, Miwa K, Ngara T, Tanabe K (eds). IGES: Tokyo, Japan.

Janik LJ, Skjemstad JO, Shepherd KD, Spouncer LR. 2007. The prediction of soil carbon fractions using mid-infrared-partial least square analysis. Australian Journal of Soil Research 45: 73-81.

Keeley JE, Lubin D, Fotheringham CJ. 2003. Fire and grazing impacts on plant diversity and alien plant invasions in the southern Sierra Nevada. Ecological Applications 13: 1355-1374.

Keith DA. 1996. Fire-driven extinction of plant populations: a synthesis of theory and review of evidence from Australian vegetation. Proceedings of the Linnean Society of New South Wales 116: 37-78.

Kimetu JM, Lehmann J, Kinyangi JM, Cheng CH, Thies J, Mugendi DN, Pell A. 2009. Soil organic C stabilization and thresholds in C saturation. Soil Biology and Biochemistry 41: 2100-2104.

Kingsford RT. 2000. Ecological impacts of dams, water diversions and river management on floodplain wetlands in Australia. Austral Ecology 25: 109-127.

Kirschbaum MUF. 2006. The temperature dependence of organic-matter decomposition - still a topic of debate. Soil Biology and Biochemistry 38: 2510-2518.

Knorr W, Prentice IC, House JI, Holland EA. 2005. Long-term sensitivity of soil carbon turnover to warming. Nature 433: 298-302.

Lal R. 2004. Soil carbon sequestration impacts on global climate change and food security. Science 403: 1623-1627.

Lal R. 2010. Carbon sequestration in saline soil. Journal of Soil Salinity and Water Quality 1: 30-40.
Lal R, Hassan HM, Dumanski JM. 1999. Desertification control to sequester carbon and mitigate the greenhouse effect. In Carbon Sequestration in Soils: Science, Monitoring Beyond NJ. Rosenberg RC, Izaurralde Malone EL (eds). Battelle Press: Columbus, OH; 83-107.

Leadley P, Pereira HM, Alkemade R, Fernandez-Manjarrés JF, Proença V, Scharlemann JPW, Walpole MJ. 2010. Biodiversity Scenarios: Projections of 21st Century Change in Biodiversity and Associated Ecosystem Services. Secretariat of the Convention on Biological Diversity: Montreal; Technical Series No. 50, 132 p.

Lehmann J, Joseph S. 2009a. Biochar for environmental management: an introduction (Ch. 1). In Biochar for Environmental Management: Science and Technology, Lehmann J, Joseph S (eds). Earthscan: London; 1-12

Lehmann J, Joseph S. 2009b. Biochar Systems (Ch. 9). In Biochar for Environmental Management: Science and Technology, Lehmann J, Joseph S (eds). Earthscan: London; 147-168

Linton DM, Warner GF. 2003. Biological indicators in the Caribbean coastal zone and their role in integrated coastal management Ocean and Coastal Management 46: 261-276.

Losos JB, Schluter D. 2000. Analysis of an evolutionary species-area relationship. Nature 408: 847-850.

MA (Millennium Ecosystem Assessment). 2005. Ecosystems and Human Well-Being: Current State and Trends: Findings of the Condition and Trends Working Group, Hassan R, Scholes R, Ash N (eds). Island Press: Washington, DC.

Matarczyk JA, Willis AJ, Vranjic JA, Ash JE. 2002. Herbicides, weeds and endangered species: management of bitou bush (Chrysanthemoides monilifera ssp. rotundata) with glyphosate and impacts on the endangered shrub, Pimelea spicata. Biological Conservation 108: 133-141.

Mazzucato M, Niemeijer D. 2000. Rethinking Soil and Water Conservation in a Changing Society: A Case Study From Burkina Faso. Tropical Resource Management Papers 32 . Wageningen University and Research Centre: Wageningen; 378.

McHenry MT, Wilson BR, Lemon JM, Donnelly DE, Growns IG. 2006. Soil and vegetation response to thinning White Cypress Pine (Callitris glaucophylla) on the North Western Slopes of New South Wales, Australia. Plant and Soil 285: 245-255.

McKinsey \& Co. 2009. Pathways to a Low-Carbon Economy. Version 2 of the Global Greenhouse Gas Abatement Cost Curve. McKinsey \& Co: London.

McLaughlin A, Mineau P. 1995. The impact of agricultural practices on biodiversity. Agriculture, Ecosystems and Environment 55: 201-212.

Meynecke J-O. 2004. Effects of global climate change on geographic distributions of vertebrates in North Queensland. Ecological Modelling 174: $347-357$.

Moreira FMS, Huising EJ, Bignell DE (eds). 2008. A Handbook of Tropical Soil Biology Sampling and Characterization of Below-Ground Biodiversity. Earthscan: London.

Nelson R, Kokic P, Crimp S, Martin P, Meinke H, Howden SM, de Voil P, Nidumolu U. 2010. The vulnerability of Australian rural communities to climate variability and change: Part II-Integrating impacts with adaptive capacity. Environmental Science and Policy 13: 18-27.

Novacek MJ, Cleland EE. 2001. The current biodiversity extinction event: Scenarios for mitigation and recovery. Proceedings of the National Academy of Sciences of the United States of America 98: 5466-5470.

Penman J, Gytarsky M, Hiraishi T, Krug T, Kruger D, Pipatti R, Buendia L, Miwa K, Ngara T, Tanabe K, Wagner F (eds). 2003. Good Practice Guidance for Land Use, Land-Use Change and Forestry. IPCC National Greenhouse Gas Inventories Programme IGES: Hayama, Japan.

Penman TD, Binns DL, Shiels RJ, Allen RM, Kavanagh RP. 2008. Changes in understorey plant species richness following logging and prescribed burning in shrubby dry sclerophyll forests of south-eastern Australia. Austral Ecology 33: 197-210.

Penman TD, Pike DA, Webb JK, Shine R. 2010. Predicting the impact of climate change on Australia's most endangered snake, Hoplocephalus bungaroides. Diversity and Distributions 16: 109-118.

Porter J, Costanza R, Sandhu H, Sigsgaard L, Wratten S. 2009. The value of producing food, energy and ecosystem services within an agro-ecosystem. Ambio 38: 186-193.

Pretty JN, Noble AD, Bossio D, Dixon J, Hine RE, Penning de vries FWT, Morison JIL. 2006. Resource-conserving agriculture increases yields in 
developing countries. Environmental Science and Technology 40: 11141119.

Reed MS, Buenemann M, Atlhopheng J, Akhtar-Schuster M, Bachmann F, Bastin G, Bigas H, Chanda R, Dougill AJ, Essahli W, Evely AC, Fleskens L, Geeson N, Glass JH, Hessel R, Holden J, Ioris A, Kruger B, Liniger HP, Mphinyane W, Nainggolan D, Perkins J, Raymond CM, Ritsema CJ, Schwilch G, Sebego R, Seely M, Stringer LC, Thomas R, Twomlow S, Verzandvoort S. 2011. Cross-scale monitoring and assessment of land degradation and sustainable land management: a methodological framework for knowledge management. Land Degradation \& Development 22: 261-271.

Reynolds JF, Stafford-Smith DM, Lambin EF, Turner BL, Mortimore M, Batterbury SPJ, Downing TE, Dowlatabadi H, Fernandez RJ, Herrick JE, Huber-Sannwald E, Jiang H, Leemans R, Lynam T, Maestre FT, Ayarza M, Walker B. 2007. Global desertification: building a science for dryland development. Science 316: 847-851.

Reynolds JF, Grainger A, Stafford Smith DM, Bastin G, Garcia-Barrios L, Fernández RJ, Janssen MA, Jürgens N, Scholes RJ, Veldkamp A, Verstraete MM, von Maltitz G, Zdruli P. 2011. Scientific concepts for an integrated analysis of desertification. Land Degradation \& Development 22: 166-183.

Roberts K, Gloy B, Joseph S, Scott N, Lehmann J. 2010. Life cycle assessment of biochar systems: estimating the energetic, economic, and climate change potential. Environmental Science and Technology 44: 827-833.

Sampaio G, Nobre C, Costa MH, Satyamurty P, Soares-Filho BS, Cardoso M. 2007. Regional climate change over eastern Amazonia caused by pasture and soybean cropland expansion. Geophysical Research Letters 34: L17709.

Sandhu HS, Stephen D, Wratten SD, Cullen R, Case B. 2008. The future of farming: the value of ecosystem services in conventional and organic arable land. An experimental approach. Ecological economics 64: 835848.

Savidge JA. 1987. Extinction of an island forest avifauna by an introduced snake. Ecology 68: 660-668.

Schimel DS, Braswell BH, Holland EA, McKeown R, Ojima DS, Painter TH, Parton WJ, Townsend AR. 1994. Climatic, edaphic, and biotic controls over storage and turnover of carbon in soils. Global Biogeochemical Cycles 8: 279-293.

Secretariat of the CBD. 2004. Addis Ababa Principles and Guidelines for the Sustainable Use of Biodiversity (CBD Guidelines) Montreal: Secretariat of the Convention on Biological Diversity; $21 \mathrm{p}$.

Smith R, Adams M, Gittins S, Gherardi S, Wood D, Meier S, Stovold R, Donald G, Khokar S, Allen A. in press. Near real-time feed on Offer from MODIS. International Journal of Remote Sensing.

Streck C, Coren M, Scherr SJ, Shames S, Jenkins M, Waage S. 2010. An African Agricultural Carbon Facility: Feasibility Assessment and Design Recommendations. Forest Trends, The Katoomba Group, EcoAgriculture Partners, Climate Focus. http://www.climatefocus.com/documents/ files/study_african_agricultural_carbon_facility.pdf also http://www. ecoagriculture.org/documents/files/doc_330.pdf.

Suleimenov M, Thomas RJ. 2007. Central Asia: Ecosystems and carbon sequestration challenges. In Climate Change and Terrestrial Carbon Sequestration in Central Asia, Lal R, Suleimenov M, Stewart BA, Hansen DO, Doraiswamy P (eds). Taylor \& Francis: London; 165-176.
Tasker EM, Bradstock RA. 2006. Influence of cattle grazing practices on forest understorey structure in north-eastern New South Wales. Austral Ecology 31: 490-502.

Telemeco RS, Elphick MJ, Shine R. 2009. Nesting lizards (Bassiana duperreyi) compensate partly, but not completely, for climate change. Ecology 90: 17-22.

Theurillat JP, Guisan A. 2001. Potential impact of climate change on vegetation in the European Alps: a review. Climatic Change 50: 77109.

Tighe M, Reid N, Wilson B, Briggs S. 2009. Invasive native scrub and soil condition in semi-arid south-eastern Australia. Agriculture, Ecosystems and Environment 132: 212-222.

Tilman D, Downing JA. 1994. Biodiversity and stability in grasslands. Nature 367: 363-365.

Tongway D, Ludwig J. 1996. Rehabilitation of semiarid landscapes in Australia. I. Restoring productive soil patches. Restoration Ecology 4: 38, 8-397.

Tongway DJ, Ludwig JA. 2005. Heterogeneity in arid and semi-arid lands. In Ecosystem Function in Heterogeneous Landscapes, Lovett GM, Turner MG, Jones CG, Weathers KC (eds). Springer: New York, NY; 189-205.

UN. 1987. Report of the World Commission on Environment and Development General Assembly Resolution 42/187, 11 December 1987.

UNCCD. 2007. Report of the Conference of the Parties on Its Eighth Session, held in Madrid from 3 to 14 September 2007. Addendum: Part two: Action taken by the Conference of the Parties at Its Eighth Session Bonn: UNCCD Document Code ICCD/COP(8)/16/Add.1

UNCCD. 2009. Report of the Conference of the Parties on its Ninth Session, held in Buenos Aires from 21 September to 2 October 2009. Addendum: Part two: Action taken by the Conference of the Parties at Its Ninth Session. Bonn: UNCCD document code ICCD/COP(9)/18/Add.1.

UNFCCC. 2007 Bali Action Plan Decision-/CP.13 http://unfccc.int/files/ meetings/cop_13/application/pdf/cp_bali_action.pdf.

UNFCCC. 2009a Draft decision-/CP.15 Methodological guidance for activities relating to reducing emissions from deforestation and forest degradation and the role of conservation, sustainable management of forests and enhancement of forest carbon stocks in developing countries. http://unfccc.int/files/na/application/pdf/cop15_ddc_auv.pdf.

UNFCCC. 2009b. Least Developed Countries under the FCCC. http:// unfccc.int/resource/docs/publications/ldc_brochure2009.pdf.

Uphoff N, Ball AS, Fernandes E, Herren H, Husson O, Laing M, Palm C, Pretty J, Sanchez P, Sanginga N, Thies J. 2006. Biological Approaches to Sustainable Soil Systems. CRC Press/Francis \& Taylor: London.

Vågen T-G, Lal R, Singh BR. 2005. Soil carbon sequestration in subSaharan Africa: a review. Land Degradation \& Development 16: 53-71.

Visser ME, Both C. 2005. Shifts in phenology due to global climate change: the need for a yardstick. Proceedings of the Royal Society of London Series B-Biological Sciences 272: 2561-2569.

Walker BH, Salt DA. 2006. Resilience Thinking: Sustaining Ecosystems and People in a Changing World. Island Press: Washington, DC.

Winkler DW, Dunn PO, McCulloch CE. 2002. Predicting the effects of climate change on avian life-history traits. Proceedings of the National Academy of Sciences of the United States of America 99: 13595-13599.

Woelke J, Tennigkeit T. 2009. Harvesting agricultural carbon in Kenya. Rural 21: 29-31. 